\title{
Analysis of Fraud Behavior Factors (The Survey of Corruption Inmates at the Class IIA Penitentiary Padang)
}

\author{
Efrizal Syofyan', Sanny Dwita ${ }^{2}$, Silsiya Afridona ${ }^{3}$ \\ ${ }^{1}$ Universitas Negeri Padang, Padang and Indonesia, $\square$ efrizal_syofyan@yahoo.com \\ ${ }^{2}$ Universitas Negeri Padang, Padang and Indonesia, $\square$ sanydwita@gmail.com \\ ${ }^{3}$ Universitas Negeri Padang, Padang and Indonesia, $\square$ silsiyaafridona@gmail.com
}

\begin{abstract}
The existence of accounting in both the private and government sectors can not be separated from fraud. Fraud in accounting is generally caused by the urge to take advantage of opportunities or can also be caused by pressure from management to do structured fraud. Therefore, this research was conducted to analyze tha factors that triggered the fraud behavior among the corruption inmate in Padang Penitentiary. This research is a causative research. And the population is all corruption prisoners at Class II A Penitentiary Padang. The sampling used total sampling, so that all population was taken as the sample of this research. Data collecting methods used is questionnaire. The analyze methods is multiple regression analysis, with the pressure, opportunity, rationalization, and understanding of fraud as the exogenous variables, and fraud behavior as the endogenous.
\end{abstract}

Keywords: Pressure, opportunity, rationalization, understanding, fraud behavior.

\section{Introduction}

The implementation of accounting in the private and public sectors will not be far from fraud, both on a small scale and large scale. Accounting fraud is generally caused by the urge to take advantage of opportunities or can also be caused by management pressure to make structured fraud. Fraud is a deception deliberately practiced in order to secure unfair unlawful gain. Fraud comes in many shapes dan sizes. It goes by several different names, including internal fraud, occupational fraud, or employee dishonesty. There are three basics types of fraud namely asset missappropriation, bribery and corruption, and financial statement. Many fraud schemes are perpetrated by employees (Coenen, 2014).

Although the asset missappropriation is a kind of fraud that most happened in private or public sector, but bribery and corrupton are the second fraud that people often do. Corporate fraud, bankruptcies, and various illegal acts have always been part of the business environment. Every time fiascos erupt there is a shock, but business history records dozens of major failures, frauds, and other measures of massive corruption each decade. The big ones often hit during recessions or periods of other economic problems, as expected. The high-risk firms are the most vulnerable to economic shocks (Giroux, 2014).

There should be a strong internal control within an organization especially in governmental as a public services sector. When it comes to fraud in the public sector, issues such as bribery, corruption, and misuse of authority during public procurement often come to mind. These practices usually involve misuse of entrusted power for personal gain, often including cash given "under the table" so there is very little or no financial statement evidence that a crime has occurred. Such crimes are uncovered in most cases through tips or complaints from third parties, often via a fraud hotline, or are detected during internal reviews, external audits, and by financial inspections.

Frauds within the public sector, including State-Owned Enterprises (SOEs), originate from both internal and external sources. Internal frauds can be committed by any employee at any level within the organization. They can range from small-scale abuse of travel expenses to large-scale frauds involving high-value contracts and breaches of controls that could have serious and material consequences. There is another examples bribery and corruption that mentioned as fraud and illegal 
activities include money laundering (the transforming of profits of crime and corruption into legitimate assets); tax evasion (the deliberate reporting of false information in tax reporting); and informality (economic activity that is not taxed or monitored by governments). All of these subject matters were generated from a fraud triangle theory by Cressey (1953), whose said that the facors which triggered the fraud behavior include pressure, opportunity, and rationalization.

Based on that description, the researcher was motivated to analyze the factors that caused people doing fraud and try to prove the causative factors why people do bribery and corruption exactly. The first factors to be analyzed is pressure. Perceived pressure refers to the factors that lead to unethical behaviors. Every fraud perpetrator faces some pressure to commit unethical behavior (Mansors, Noorhayati; Abdullahi, 2015). These pressures can either be financial of non-financial pressures. The second necessary element of fraud to occur is perceived opportunity. Opportunity is created by ineffective control or governance system that allows an individual to commit organizational fraud. In the field of accounting, this is termed as internal control weaknesses. The concept of perceived opportunity suggests that people will take advantage of circumstances available to them (Kelly, Hartley, Kelly, \& Hartley, 2010). The rationalization is the third element of the fraud behavior factor. This concept indicates that the perpetrator must formulate some morally acceptable idea to him before engaging in unethical behavior. Rationalization refers to the justification and excuses that the immoral conduct different from criminal activity. If an individual cannot justify dishonest actions, it is unlikely that he or she will engage in fraud. Some examples of rationalizations of fraudulent behavior include "I was only borrowing the money", "I was entitled to the money because my employer is cheating me" (Mansors, Noorhayati; Abdullahi, 2015).

There is one other factor that assumed as the trigger factor why the people do fraud such as corruption, that is the understanding of what fraud is from fraudulent. Many of fraudulent do not understand that they have done a kind of fraud, they didn't aware of it. Less understanding about taxation is one of condition which caused people do fraud. The understanding of fraud was taken as another variable in this research. Truly, there have never been any research discussed about this variable, that is why the researcher is motivated to observed the understanding of fraud as another variablein this research.

The behavior to do fraud is nowadays become a system that individual in public sectors did not aware, then finally the perpetrator was trapped in jail as a corruption inmate. Based on data from the Padang Corruption Court, out of the 35 corruption cases that were registered until the beginning of December 2018, 23 of these cases have been decided by the panel of judges, while 12 other cases are still in the court process, either before the trial or meeting. Meanwhile, based on the classification of cases during 2018, 22 cases were related to corruption cases in state financial management, 10 cases related to illegal levies, three cases of money laundering (TPPU), and two joint cases management of state finances with TPPU. Some of these case have been severed and some are still in the court process. However, there are still opportunities for additional corruption cases from the West Sumatra Prosecutors and state prosecutor's office, those are new five cases are registered but they have not been completed administratively so that it cannot be proceed (https://www.harianhaluan.com). It is needed to be analyzed whether those four factors as the triggered. That's why the researcher conducted this research.

\section{Methods}

This research type is a causative research, which the population is all corruption prisoners at Class II A Penitentiary Padang which amounted to 61 prisoners. The sampling used total sampling, so that all population is treated as the sample of this research. The research data is primary. Data collecting methods used is questionnaire. The analyze methods is multiple regression analysis, with the pressure, opportunity, rationalization, and comprehension as the variables to be analyzed as the factors that triggered fraud behavior among the corruption inmates. 


\section{Results and Discussion}

This research is aimed to obtained the contribution of the pressure, opportunity, rationalization and factors in triggerring the fraud behavior among the corruption inmates. From the results of the research it can be seen that adjusted $\mathrm{R}$ Square $=0.753$, meaning that the contribution of exogenous variables to the endogenous variable is $75.3 \%$, while $24.7 \%$ is determined by other variables. The constant value of 0.319 shows that without the factors of pressure, rationality, and opportunity, Fraud's behavior has reached the level of 0.319 . The results shown in Table I, as follows.

Table I Empirical Relationship between Components of the Models

\begin{tabular}{|c|c|c|c|c|c|c|}
\hline & \multirow[t]{2}{*}{ Model } & \multicolumn{2}{|c|}{$\begin{array}{c}\text { Unstandardized } \\
\text { Coefficients }\end{array}$} & \multirow{2}{*}{$\begin{array}{c}\text { Standardized } \\
\text { Coefficients }\end{array}$} & \multirow[t]{2}{*}{$t$} & \multirow[t]{2}{*}{ Sig. } \\
\hline & & B & Std. Error & & & \\
\hline \multirow[t]{5}{*}{1} & (Constant) & 2.540 & 2.118 & & 1.199 & .236 \\
\hline & X1 : Pressure & .053 & .067 & .083 & 1.049 & .437 \\
\hline & X2: Opportunity & .280 & .121 & .325 & 2.320 & .025 \\
\hline & X3 : Rationalization & .756 & .246 & .696 & 3.076 & .003 \\
\hline & X4 : Understanding & -.365 & 278 & -215 & -1.313 & 196 \\
\hline
\end{tabular}

a. Dependent Variable: Y : Fraud Behavior

Based on the analysis, the pressure variable is not significantly impact on the fraud behavior with the coefficient of regresion is $0.053, t_{\text {count }}$ is 1.049 , ( $\operatorname{Sig} 0.437>0.05$ ). The opportunity variable is significantly impact on the fraud behavior with the coefficient of regression is 0.280 , $t_{\text {count }}$ is 2.320 , (Sig $0.025<0.05$ ). While the rationalization variable gives significantly impact in triggering the fraud behavior with the coefficient of regression is 0.756 , $t_{\text {count }}$ is 3.076 , (Sig $0.003<0.05$ ). This analysis reveal that the rationalization give the strongest influence in triggering the fraud behavior among the corruption inmate at a penitentiary Padang. This results support the hypothesis of $\mathrm{H}_{2}$ and $\mathrm{H}_{3}$, but it don't support $\mathrm{H}_{1}$ and $\mathrm{H}_{4}$.

From the research data analysis, overall it can be said that the pressure and understanding variables don't contribute in triggering the corruption inmates to do fraud, while the other two variables such as opportunity and rationalization have impacted significantly on the fraud behavior. This in line with the research that conducted by Dellaportas (2013), which the research results revealed that the strength of opportunity in the advent of fraud suggesting that opportunity rather than motivation is a better predictor of deviant behaviour as well being the key to controlling fraud. That is not to say a sufficiently motivated person will not pursue illegal behaviour, but it is opportunity that allows a would-be offender to seek a solution through illegitimate means. The implications if his research calls for an orientation of research that is focused on controlling fraud not by eradicating motivation but restricting opportunity.

The samples of corruption inmates taken in this research is limited due to the restricted to the perpetrators who serve the custodial. The protocol interview and time constraints imposed by prison officials provided is limited opportunity to pursue follow up or probing questions. All these matters thus limiting its overall generalisability.

It is suggested that the factors which triggered the fraud behavior are needed to socialize to the people who work for an organization, both in private or public sectors. The related parties should concern about conducting socialization of what is bribery, corruption, and the governing law to the people. So that it is supposed to minimize corruption.

\section{Conclusions}

This study aimed to analyze the effect of pressure, opportunity, rationalization and capability on fraud behavior on prisoners of corruption in the Class II A at the Class II A Penitentiary Padang. 
Based on the results of research and hypothesis testing that has been done, the results of this study indicate that, simultaneously the four variables related to fraudulent motives have a significant effect on the occurrence of fraud. But partially, only factors of opportunity and rationalization have a positive significant effect on fraud. While the pressure and understanding do not significantly influence fraud behavior. The understanding of fraud variable was supposed to be a variable that significantly impacted on the fraud behavior, but this research revealed that it did not. It can be assumed that the limitations of researcher access to distribute the questionairre in the penitentiary to the corruption inmate. Therefore the researcher gives suggestions to the next researcher to be developed by adding research variables such as weak internal control, unethical behavior, aspects of legislation and aspects of supervision. It is also expected for further research to expand the sample so that results can be generalized and use data collection techniques in the form of interviews.

\section{References}

Ajzen, I., \& Fishbein, M., (1975). Belief, Attitude, Intention, and Behavior: An Introduction to Theory and Research, 129-385, Addison-Wesley, Reading, MA.

Anand, V., Blake, E. A., \& Joshi, M. (2004). Business as usual: The acceptance and perpetuation of corruption. Academy of Management Executive, 18 (2), 39-53.

Black, Henry Campbell, (1990). Black Law Divtionary, Definition of the term and Phrase and Phrase of American and English yurisprudence, Ancient and Modern, St. Minnesota, west Publishing Co.

Davidson, Daniel V, et all, (1987). Comprehensive Bussines law Priciples and Cases, Kent Publising Company.

Cressey, D.R. (1953), Other People's Money: A Study in the Social Psychology of Embezzlement, Patterson Smith, Montclair, NJ.

Giroux, G. (2014). What Went Wrong? Accounting Fraud and Lessons from the Recent Scandals, 75(4), 1205-1238.

Kelly, P., Hartley, C. A., Kelly, P., \& Hartley, C. A. (2010). Casino gambling and workplace fraud : a cautionary tale for managers. https://doi.org/10.1108/01409171011030381

Mansors, Noorhayati; Abdullahi, R. (2015). Fraud Triangle Theory and Fraud Diamond Theory . Understanding the Convergent and Divergent For Future Research, 5(4), 38-45. https://doi.org/10.6007/IJARAFMS/v5-3/1823

Tuanakotta, Theodorus M. 2013. Mendeteksi Manipulasi Laporan Keuangan. Jakarta: Salemba Empat. 